\title{
Potential application of waste from castor bean (Ricinus communis L.) for production for xylanase of interest in the industry
}

\author{
Polyanna Nunes Herculano ${ }^{1,2}$ - Keila Aparecida Moreira $^{3}$ - Raquel Pedrosa Bezerra ${ }^{2}$. \\ Tatiana Souza Porto ${ }^{3}$ Cristina Maria de Souza-Motta ${ }^{1}$ Ana Lúcia Figueiredo Porto ${ }^{2}$
}

Received: 15 March 2016/Accepted: 11 June 2016/Published online: 23 June 2016

(c) The Author(s) 2016. This article is published with open access at Springerlink.com

\begin{abstract}
Xylanases activity (XY) from Aspergillus japonicus URM5620 produced by Solid-State Fermentation (SSF) of castor press cake (Ricinus communis) on different conditions of production and extraction by PEG/ citrate aqueous two-phase system (ATPS) were investigated. XY production was influenced by substrate amount (5-10 g), initial moisture (15-35\%), pH (4.0-6.0) and temperature $\left(25-35^{\circ} \mathrm{C}\right)$, obtaining the maximum activity of $29,085 \pm 1808 \mathrm{U} \mathrm{g} \mathrm{ds}^{-1}$ using $5.0 \mathrm{~g}$ of substrate with initial moisture of $15 \%$ at $25^{\circ} \mathrm{C}$ and $\mathrm{pH} 6.0$, after $120 \mathrm{~h}$ of fermentation. The influence of PEG molar mass (1000-8000 $\mathrm{g} \mathrm{mol}^{-1}$ ), phase concentrations (PEG 20.0-24.0\% w/w and sodium citrate $15-20 \% \mathrm{w} / \mathrm{w})$ and $\mathrm{pH}(6.0-8.0)$ on partition coefficient, purification factor, yield and selectivity of $\mathrm{XY}$ were determinate. Enzyme partitioning into the PEG rich phase was favored by $M_{\mathrm{PEG}}$ $8000\left(\mathrm{~g} \mathrm{~mol}^{-1}\right), C_{\mathrm{PEG}} 24 \%(\mathrm{w} / \mathrm{w}), C_{\mathrm{C}} 20 \%(\mathrm{w} / \mathrm{w})$ and $\mathrm{pH}$ 8.0 , resulting in partition coefficient of 50.78 , activity yield of $268 \%, 7.20$-fold purification factor and selectivity of 293. A. japonicus URM5620 has a potential role in the development of a bioprocess for the XY production using low-cost media. In addition, the present study proved it is feasible to extract xylanase from SSF by adopting the one step ATPS consisting of PEG/citrate.
\end{abstract}

Raquel Pedrosa Bezerra

rpbezerra@yahoo.com.br

1 Mycology Department, Federal University of Pernambuco, Recife, PE, Brazil

2 Animal Morphology and Physiology Department, Federal Rural University of Pernambuco, Av. Dom Manoel de Medeiros s/n, Recife, PE 52171-900, Brazil

3 Academic Unit of Garanhuns, Federal Rural University of Pernambuco, Garanhuns, PE, Brazil
Keywords Xylanase $\cdot$ Production $\cdot$ Solid-state fermentation - Aqueous two phase systems . Aspergillus japonicus

\section{Introduction}

With the increasing concern to valorize the waste material constantly generated, there is considerable interest in the establishment of efficient processes to obtain valuable products from residues that permit the recovery of commercially attractive products from a wide variety of residues (Soccol et al. 2011). In addition, the growing bioprocess industry depends on the progressive reduction of expensive nutrient inputs into fermentation media. The potential production and recovery of enzymes from microbial using cheap agricultural by-products such as castor press cake (Ricinus communis) improve the commercial feasibility of bioprocess technology. About $1 \mathrm{Mt}$ of castor beans is harvested annually for castor oil production, with India, China, and Brazil being major producers (Mutlu and Meier 2010).

Xylan is the second most abundant polysaccharide in nature and it is the major hemicellulosic polysaccharide of wood and agricultural wastes, where it comprises up to 20-35\% dry weight. Considering the nutritional composition of castor press cake, commercial applications for such a valuable material, hitherto, considered a waste in most developing countries need to be explored and one such application could be their use as a substrate for xylanase enzyme production. Xylanase (XY) is the main enzyme which degrades linear polysaccharide $\beta$-1,4-xylan into xylose, thus breaking down hemicelluloses (Irfan et al. 2014). The design of efficient production and recovery protocols that allow the use of raw material to enzymes production is one of the key goals in the field. 
High production cost and low production yields had caused the bottleneck for industrial enzyme applications, thus alternate enzyme production method using cheaper ingredient with higher yield is necessary. Several works using different substrates has been made to increase enzyme production and reduce production costs (Ang et al. 2013; Pandya and Gupta 2012). SSF is advantageous since it has greater volumetric productivities, higher product stability, low contamination risk and lower instrumental costs. Another advantage is the use of cheap solid agrolignocellulose wastes which acts as carbon and energy source and further reduce the need of expensive nutrient medium. Aspergillus sp. was commonly classified as strong xylanase producer (Collins et al. 2005).

Aspergillus japonicus URM5620 cultivated in the SSF with castor bean meal as carbon source produces (hemi) cellulase enzymes in a shorter period with cheap and available raw material (Herculano et al. 2012). Particularly, Aspergillus sp. are considered representative model to production of commercial interest substances (Khammuang and Sarnthima 2007). The world market of xylanase is expanding speedily due to its enormous pivotal roles in various industries, particularly in the biotechnology applications, including pulp and paper, baking, animal feed, detergent, food and beverage (Ho and Lau 2014).

The downstream processing (DSP) of biomolecules is often representing a major bottleneck of the whole production process in terms of complexity and high cost, which can make up more than $70 \%$ of the total DSP product cost (Raja et al. 2011). In this context, aqueous two-phase system (ATPS) is a promising downstream processing to sensitive biomolecules and biotechnological products (Glyk et al. 2015). PEG/salt characteristics have been exploited for several biomolecules extraction by to be primary recovery technique that integrates the concentration and partial purification of important biomolecules from their natural source in a single step (Rito-Palomares and Lyddiatt 2002).

In this context, the purpose of this study was to evaluate the production of xylanase (XY) from A. japonicus URM5620 by Solid-State Fermentation (SSF) of castor press cake (Ricinus communis) and exploits the partition and purification of xylanase in ATPS made up of PEG/ citrate.

\section{Materials and methods}

\section{Castor bean meal}

The castor bean meal used in this study was supplied by the Brazilian Agricultural Research Corporation, EMBRAPA/ Agribusiness Tropical, located in Fortaleza, Ceará, Brazil, which is currently developing a Programme of Development of Castor in the State (Rodrigues 2007; Oliveira et al. 2013).

\section{Microorganism}

The culture A. japonicus URM5620 utilized in this study was obtained from the Mycology Department's Mycoteca-URM, at Federal University of Pernambuco, Brazil. The strain was maintained on Malt Extract agar and kept at $28{ }^{\circ} \mathrm{C}$ for 7 days.

\section{Xylanase production (XY) by SSF}

For XY production, castor cake was used as the substrate with a particle size between 3 and $8 \mathrm{~mm}$ to provide improved absorption and porosity to facilitate transport of oxygen and nutrients during SSF (Spier et al. 2008). The substrate was autoclaved at $120{ }^{\circ} \mathrm{C}$ for $15 \mathrm{~min}$ in Erlenmeyer flasks of $250 \mathrm{~mL}$. The inoculum was prepared by suspending the spores present on the malt extract agar plates in $0.05 \mathrm{M}$ citrate buffer. The number of spores was determined in a Neubauer counting chamber, and the inoculum of $10^{7}$ spores per gram of dry weight was inoculated in the substrate used for SSF. The initial moisture of the substrate was determined in accordance with the standards of the Instituto Adolfo Lutz (2005). Substrate was dried at $105{ }^{\circ} \mathrm{C}$ for until constant weight and $100 \%$ moisturization was achieved by adding of distilled water on substrate. Dry solid substrate was mixed with predetermined amount of distilled water until achieve required initial moisture.

\section{Preparation of the enzymatic extract}

The XY production was followed for $120 \mathrm{~h}$. The contents of the flasks were harvested at regular intervals $(24 \mathrm{~h})$ by adding $0.05 \mathrm{M}$ citrate buffer, (each $1 \mathrm{~g}$ of substrate: $2.5 \mathrm{~mL}$ of buffer), incubated in a temperature controlled bath at $32{ }^{\circ} \mathrm{C}$ for a period of $1 \mathrm{~h}$ and filtered with filter paper (Whatman No. 1) under vacuum. The supernatant was used as enzymatic extract crude and subjected to enzymatic analysis (Herculano et al. 2011).

\section{Preparation of aqueous two-phase systems}

Aqueous two phase systems (ATPS) were prepared in $15 \mathrm{~mL}$ graduated tubes by mixing appropriate amounts of $50 \%$ w/w stock solutions of different molecular weights PEG (1000, 3350 and $\left.8000 \mathrm{~g} \mathrm{~mol}^{-1}\right), 50 \% \mathrm{w} / \mathrm{w}$ stock solution of potassium citrate, at different $\mathrm{pH}$ values (6.0, $7.0,8.0)$, at $25 \pm 1{ }^{\circ} \mathrm{C}$, according to statistical design described in the Table 2. Fermentation broth representing 
(20\% w/w) and water and was added to a final weight of $5 \mathrm{~g}$. After vortex shaking for $1.0 \mathrm{~min}$, the two phases were separated by settling for $40 \mathrm{~min}$. Then, the phase volumes were measured; top and bottom phases were separately withdrawn with pipettes and assayed for protein concentration and xylanase activity.

\section{Analytical techniques}

Protein content was determined according to Bradford (1976) at $595 \mathrm{~nm}$. Bovine serum albumin was used as a standard. XY activity was determined according to the methodology described by Bailey et al. (1992). The activity was carried out in the total reaction mixture of $1 \mathrm{~mL}$ containing $0.1 \mathrm{~mL}$ of suitably diluted enzyme and $0.9 \mathrm{~mL}$ of $1 \%(\mathrm{w} / \mathrm{v})$ of xylan (Sigma, USA) solution in sodium citrate buffer $\left(50 \mathrm{mM}, \mathrm{pH} 5.0\right.$ at $\left.60{ }^{\circ} \mathrm{C}\right)$. This reaction mixture was incubated at $50{ }^{\circ} \mathrm{C}$ for $5 \mathrm{~min}$. One unit (U) of enzyme activity was defined as the amount of enzyme required to liberate $1 \mu \mathrm{mol}$ of xylose (Vetec, Brazil) from the appropriate substrates per minute under the assay conditions. The release of reducing sugars was determined by the 3,5-dinitrosalicylic acid (DNS) method Miller (1959).

\section{Experimental design and statistical analysis}

The experiments performed according to a $2^{4}$ full factorial design with three levels plus four central points for xylanase production (Table 1) and xylanase extraction using ATPS systems (Table 2). The influence of the substrate amount ( $\mathrm{Sa}$; 5-10 g), initial moisture (Im, 15-35\%), temperature ( $T$, 25-35 ${ }^{\circ} \mathrm{C}$ ) and $\mathrm{pH}(4.0-6.0)$ on the XY production was evaluated (Table 1). The choice of variables and their levels was made according to Gao et al. (2008). In the best production condition, the XY was extracted using poly (ethylene glycol)-sodium citrate aqueous two-phase systems (ATPS). The influence of variables, namely PEG molar mass $\left(M_{\mathrm{PEG}}\right)$, PEG concentration $\left(C_{\mathrm{PEG}}\right)$, citrate concentration $\left(C_{\mathrm{C}}\right)$ and $\mathrm{pH}$ was studied on the three selected responses: purification factor $(\mathrm{PF})$, activity yield $(Y)$, partition coefficient $(K)$ and selectivity $(S)$ (Table 2). The significance of effects and two factor interactions was estimated by ANOVA. The main effect of the independent variables and their interactions on the dependent variables was investigated using Pareto chart and interaction plot. All statistical analyses were carried out using Statistica 8.0 software (StatSoft Inc., Tulsa, OK, USA).

\section{Determination of partition coefficient, purification factor, yield and selectivity}

The XY partition coefficient was defined as the ratio of the volumetric activity in the top phase $\left(A_{\mathrm{t}}\right)$ to that in the bottom phase $\left(A_{\mathrm{b}}\right)$ :
Table 1 Full factorial design for xylanase production (XY) in solidstate fermentation (SSF) by Aspergillus japonicus URM5620 under different operational conditions after $120 \mathrm{~h}$ of cultivation

\begin{tabular}{lrllllr}
\hline Run & $\mathrm{Sa}(\mathrm{g})^{\mathrm{a}}$ & $\mathrm{Im}(\%)^{\mathrm{b}}$ & $\mathrm{pH}^{\mathrm{c}}$ & $\mathrm{T}\left({ }^{\circ} \mathrm{C}\right)^{\mathrm{d}}$ & \multicolumn{2}{l}{$\mathrm{XY}$} \\
\cline { 4 - 6 } & & & & & $\left(\mathrm{U} \mathrm{g} \mathrm{ds}^{-1}\right)^{\mathrm{e}}$ & $\left(\mathrm{U} \mathrm{mg}^{-1}\right)^{\mathrm{f}}$ \\
\hline 1 & 5.0 & 15 & 4.0 & 25 & 8200 & 29,491 \\
2 & 5.0 & 15 & 4.0 & 35 & 401 & 1810 \\
3 & 5.0 & 35 & 4.0 & 25 & 8967 & 24,128 \\
4 & 5.0 & 35 & 4.0 & 35 & 8898 & 24,378 \\
5 & 10.0 & 15 & 4.0 & 25 & 4217 & 19,027 \\
6 & 10.0 & 15 & 4.0 & 35 & 5517 & 21,130 \\
7 & 10.0 & 35 & 4.0 & 25 & 4455 & 12,367 \\
8 & 10.0 & 35 & 4.0 & 35 & 2659 & 7880 \\
9 & 5.0 & 15 & 6.0 & 25 & 29,085 & 62,141 \\
10 & 5.0 & 15 & 6.0 & 35 & 2766 & 6256 \\
11 & 5.0 & 35 & 6.0 & 25 & 7664 & 17,032 \\
12 & 5.0 & 35 & 6.0 & 35 & 3585 & 8883 \\
13 & 10.0 & 15 & 6.0 & 25 & 4188 & 11,243 \\
14 & 10.0 & 15 & 6.0 & 35 & 7452 & 20,573 \\
15 & 10.0 & 35 & 6.0 & 25 & 4137 & 9540 \\
16 & 10.0 & 35 & 6.0 & 35 & 3075 & 7901 \\
17 & 7.5 & 25 & 5.0 & 30 & 5661 & 16,162 \\
18 & 7.5 & 25 & 5.0 & 30 & 7479 & 22,819 \\
19 & 7.5 & 25 & 5.0 & 30 & 6723 & 17,590 \\
20 & 7.5 & 25 & 5.0 & 30 & 6387 & 17,381 \\
\hline & & & & & \\
\hline
\end{tabular}

a Sa-substrate amount (g, grams), ${ }^{\mathrm{b}}$ Im-initial moisture $(\%),{ }^{\mathrm{c}} \mathrm{pH}$ and d T-temperature $\left({ }^{\circ} \mathrm{C}\right),{ }^{\mathrm{e}} \mathrm{U} \mathrm{gds}^{-1}$ - xylanase activity, ${ }^{\mathrm{f}} \mathrm{U} \mathrm{mg}{ }^{-1}$ specific xylanase activity

$K=\frac{A_{\mathrm{t}}}{A_{\mathrm{b}}}$

The purification factor was calculated as the ratio of the specific activity in the top or bottom phase to the specific activity in the cell extract before partition $\left(A_{\mathrm{i}}\right)$ :

$\mathrm{PF}=\frac{A_{\mathrm{x}} / C_{\mathrm{x}}}{A_{\mathrm{i}} / C_{\mathrm{i}}}$

where $C_{\mathrm{x}}$ and $C_{\mathrm{i}}$ are the total protein concentrations, expressed as $\mu \mathrm{g} \mathrm{mL}^{-1}$, in the top or bottom phase and initial extract, respectively.

The activity yield was determined as the ratio of total activity in the top or bottom phase to that in initial extract and expressed as percentage:

$Y=\left(\frac{A_{\mathrm{x}} \cdot V_{\mathrm{x}}}{A_{\mathrm{i}} \cdot V_{\mathrm{i}}}\right) \times 100$

where $V_{\mathrm{x}}$ and $V_{\mathrm{i}}$ are the volumes of the top or bottom phase and the initial extract, respectively.

The selectivity was defined as the ratio of the enzyme partition coefficient $\left(K_{\mathrm{e}}\right)$ to the protein partition coefficient $\left(K_{\mathrm{p}}\right)$ (Mayerhoff et al. 2004): 
Table 2 Effects of PEG molar mass $\left(M_{\mathrm{PEG}}\right)$, PEG concentration $\left(C_{\mathrm{PEG}}\right)$, citrate concentration $\left(C_{\mathrm{C}}\right)$ and $\mathrm{pH}$ on partition coefficient $(K)$, top activity yield $(Y)$, purification factor in the top phase $(P F)$, selectivity $(S)$ using $2^{4}$ experimental design to xylanase extraction by PEG/citrate ATPS

\begin{tabular}{|c|c|c|c|c|c|c|c|c|}
\hline Run & $M_{\mathrm{PEG}}^{\mathrm{a}}$ & $C_{\mathrm{PEG}}^{\mathrm{b}}$ & $C \mathrm{c}^{\mathrm{c}}$ & $\mathrm{pH}$ & $K^{\mathrm{d}}$ & $Y^{\mathrm{e}}$ & $\mathrm{PF}^{\mathrm{f}}$ & $\mathrm{S}^{\mathrm{g}}$ \\
\hline A1 & 1000 & 20 & 15 & 6.0 & 27.20 & 268.01 & 7.16 & 185.25 \\
\hline $\mathrm{A} 2$ & 8000 & 20 & 15 & 6.0 & 9.66 & 183.03 & 6.05 & 83.04 \\
\hline A3 & 1000 & 24 & 15 & 6.0 & 35.98 & 265.12 & 5.36 & 208.14 \\
\hline A4 & 8000 & 24 & 15 & 6.0 & 19.28 & 220.00 & 4.00 & 95.91 \\
\hline A5 & 1000 & 20 & 20 & 6.0 & 47.15 & 192.73 & 3.27 & 146.06 \\
\hline A6 & 8000 & 20 & 20 & 6.0 & 31.41 & 163.59 & 1.13 & 5.52 \\
\hline A7 & 1000 & 24 & 20 & 6.0 & 38.49 & 184.92 & 3.66 & 138.71 \\
\hline A8 & 8000 & 24 & 20 & 6.0 & 44.44 & 179.17 & 4.88 & 293.33 \\
\hline A9 & 1000 & 20 & 15 & 8.0 & 45.27 & 229.94 & 6.51 & 286.69 \\
\hline A 10 & 8000 & 20 & 15 & 8.0 & 24.39 & 198.47 & 6.68 & 218.78 \\
\hline A11 & 1000 & 24 & 15 & 8.0 & 28.68 & 205.94 & 3.38 & 105.20 \\
\hline A 12 & 8000 & 24 & 15 & 8.0 & 20.62 & 192.35 & 2.44 & 67.42 \\
\hline A13 & 1000 & 20 & 20 & 8.0 & 37.87 & 160.77 & 3.94 & 135.58 \\
\hline A14 & 8000 & 20 & 20 & 8.0 & 28.10 & 181.54 & 4.65 & 128.86 \\
\hline A15 & 1000 & 24 & 20 & 8.0 & 30.23 & 154.14 & 2.05 & 67.48 \\
\hline A16 & 8000 & 24 & 20 & 8.0 & 50.78 & 207.08 & 2.50 & 108.60 \\
\hline A17 & 3350 & 22 & 17.5 & 7.0 & 24.31 & 207.10 & 7.20 & 203.35 \\
\hline A18 & 3350 & 22 & 17.5 & 7.0 & 21.56 & 184.27 & 4.91 & 141.8 \\
\hline A19 & 3350 & 22 & 17.5 & 7.0 & 22.86 & 199.04 & 5.58 & 152.38 \\
\hline A20 & 3350 & 22 & 17.5 & 7.0 & 28.96 & 239.34 & 5.81 & 231.20 \\
\hline
\end{tabular}

$\overline{\mathrm{a}}$ PEG molar mass $\left(\mathrm{g} \mathrm{mol}^{-1}\right),{ }^{\mathrm{b}}$ PEG concentration $(\%),{ }^{\mathrm{c}}$ citrate concentration (\%), ${ }^{\mathrm{d}}$ partition coefficient, ${ }^{\mathrm{e}}$ top activity yield (\%), ${ }^{\mathrm{f}}$ purification factor in the top phase, ${ }^{\mathrm{g}}$ selectivity

$S=\frac{K_{\mathrm{e}}}{K_{\mathrm{p}}}$

\section{Results}

The results obtained from the 20 runs of the first experimental design are showed in Table 1. Fermentation time in all runs was $120 \mathrm{~h}$ which obtained the highest xylanase activities.

The effects of variables studied on xylanase activity were shown in Pareto Chart (Fig. 1). All principal variables and their interaction showed a significant response effect $(p<0.05)$, except the interaction between $\mathrm{S} a$ and $\mathrm{Im}$. The $\mathrm{pH}$ showed a positive and significant effect, while that increasing $\mathrm{Im}, \mathrm{Sa}$ and temperature reduces the xylanase production (Fig. 1). Xylanase production increases with increasing $\mathrm{pH}$. On the other hand, lower amount substrate, initial moisture and temperature increased $\mathrm{XY}$ by $A$. japonicus URM5620 in Solid-State Fermentation (SSF) of castor press cake (Ricinus communis). Maximum XY activity of $29,085 \pm 1808 \mathrm{U} \mathrm{g} \mathrm{ds}^{-1}$ was produced in the culture with $120 \mathrm{~h}$ of fermentation, using $5.0 \mathrm{~g}$ of substrate with initial moisture of $15 \%$ at $25{ }^{\circ} \mathrm{C}$ and $\mathrm{pH} 6.0$ (run 9; Table 1).

Figure 1 shows that temperature and substrate amount were two variables most significant in the whole set of experiments to xylanase production. Therefore, they were selected for scatter plot showing the highest $\mathrm{XY}$ activity at $25^{\circ} \mathrm{C}$ and $\mathrm{pH} 6.0$ (Fig. 2).

In the best production condition, the enzymatic extract was subjected to ATPS technique using PEG/citrate to extract and/or purify xylanase. ATPS can be effectively used in concentrating of xylanases from the crude enzymes. Table 2 shows $K$ values were higher than 1 in all runs, indicating the effectiveness of xylanase partitioning to the top phase. The highest value of $K$ was 50.7 (Run A16; Table 2).

Table 3 shows the effects of the independent variables and of each combination on dependent variables $K, Y, \mathrm{PF}$ and $S . M_{\mathrm{PEG}}$ and $C_{\mathrm{C}}$ had influence on $K$ value $(p<0.05$; Table 3). $M_{\mathrm{PEG}}$ have a negative effect indicating that lower molecular weight increase the $K$, pushing enzyme partition towards the top phase. Xylanase enzymes presents higher affinity for the PEG-rich phase, especially when PEG of low molecular weight was utilized. $C_{\mathrm{C}}$ have positive effect, 
Fig. 1 Pareto chart for the standardized effects of the variables: (1) temperature, (2) initial moisture, (3) substrate amount and (4) $\mathrm{pH}$ on activity of xylanase after $120 \mathrm{~h}$ of fermentation

Fig. 2 Scatterplot of the $S a$ and $T$ effects on the activity of xylanase (XY, $\mathrm{U} \mathrm{g} \mathrm{ds}^{-1}$ )
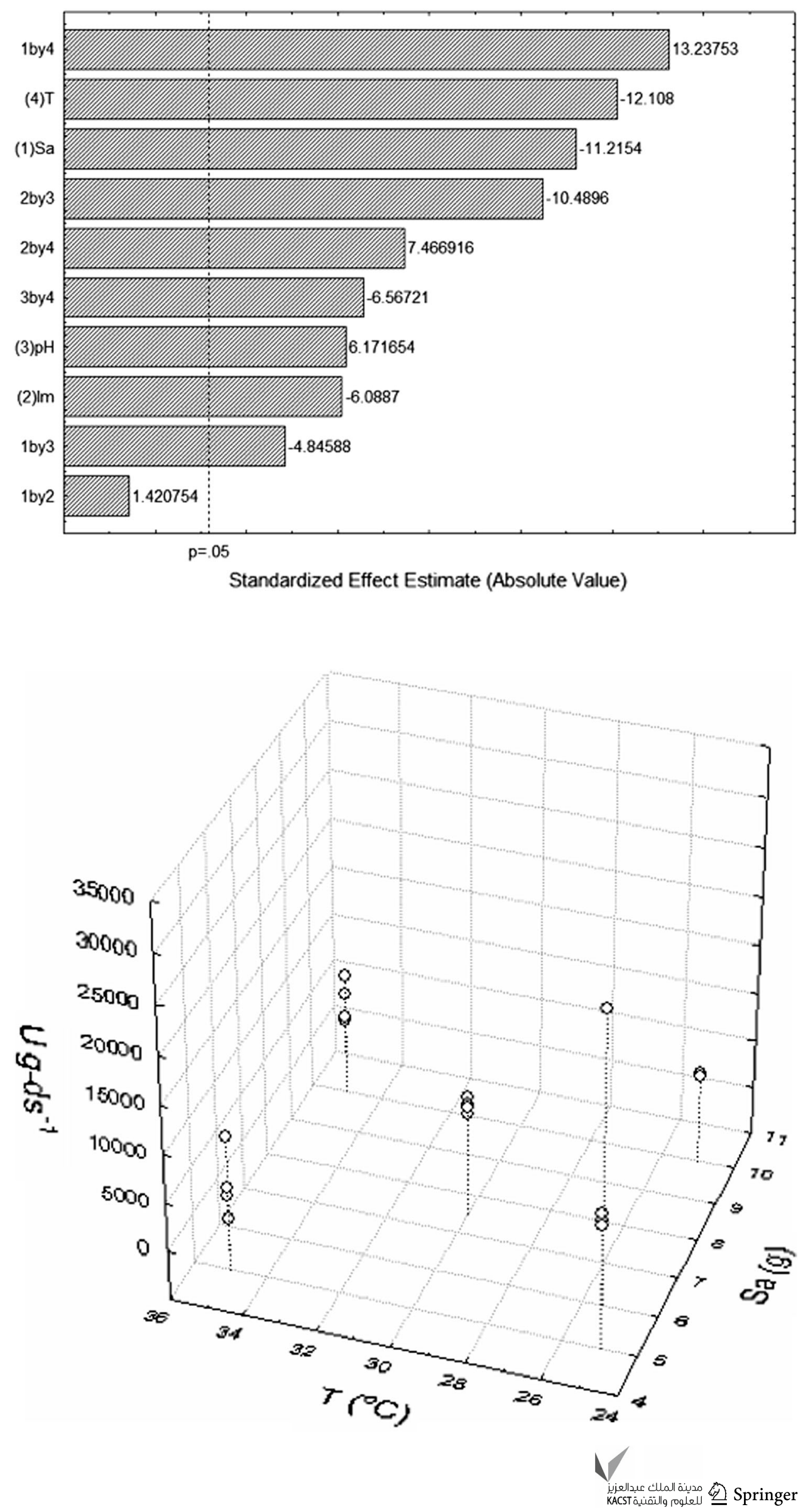
indicating that lower concentrations increase the $K$. Xylanase partition has a tendency to shift to the top phase due to salting-out effects caused by high $C_{\mathrm{C}}$ that generate the movement of the enzyme to this phase. On the other hand, $C_{\mathrm{PEG}}$ e pH not influenced statistically on $K$ values.

The value of enzymatic yield $(Y)$ on top phase varied between $154 \%$ in system A15 and $268 \%$ in system A1 (Table 2). The main effects of variables on the activity recovery in top phase of PEG-citrate systems and their significance are shown in Table 3. $C_{\mathrm{C}}$ influenced

Table 3 Effects estimates of the responses obtained of the $2^{4}$-experimental design for partition coefficient $(K)$, top activity yield $(Y)$, purification factor in the top phase $(P F)$, selectivity $(S)$ of xylanase extraction by PEG/citrate ATPS

\begin{tabular}{lcccc}
\hline & $K$ & $Y$ & $\mathrm{PF}$ & $S$ \\
\hline $1-M_{\mathrm{PEG}}$ & $-4.81^{*}$ & -1.46 & -2.60 & -1.60 \\
$2-C_{\mathrm{PEG}}$ & 1.35 & 0.32 & $-7.18^{*}$ & -0.62 \\
$3-C_{\mathrm{C}}$ & $7.54^{*}$ & $-3.64^{*}$ & $-10.0^{*}$ & -1.33 \\
$4-\mathrm{pH}$ & 0.95 & -1.35 & -2.17 & -0.22 \\
$1 * 2$ & $5.08^{*}$ & 1.21 & 1.12 & 2.14 \\
$1 * 3$ & $4.97^{*}$ & 2.29 & 2.24 & 2.17 \\
$1 * 4$ & 2.00 & 2.08 & 2.44 & 0.76 \\
$2 * 3$ & 1.65 & 0.24 & $7.31^{*}$ & 2.89 \\
$2 * 4$ & -2.17 & -0.56 & $-7.56^{*}$ & $-4.35^{*}$ \\
$3 * 4$ & -3.20 & 0.99 & 2.43 & -1.47 \\
\hline
\end{tabular}

* Statistically significant value (at the $95 \%$ confidence level, $p<0.05$ ) negatively and statistically in the $Y$ values, showing the increase in the $Y$ with lower $C_{\mathrm{C}}(15 \%)$ while the variables $M_{\mathrm{PEG}}, C_{\mathrm{PEG}}, \mathrm{pH}$ and the variable interaction not influenced in the $Y$ values (Table 3 ).

$P F$ in top phase varied between 1.13 in A6 system and 7.81 in A20 system (Table 2). The main effect of variables $M_{\mathrm{PEG}}, C_{\mathrm{PEG}}, C_{\mathrm{C}}$ and their interaction on $\mathrm{PF}$ can be observed in. Table 3. $C_{\mathrm{PEG}}, C_{\mathrm{C}}$ and interaction between $C_{\mathrm{PEG}}$ e pH had negative effects on the PF while $C_{\mathrm{PEG}}$ and $C_{\mathrm{C}}$ interaction had positive effects on the response (Fig. 3). The negative interaction effects of $C_{\mathrm{PEG}}$ and $\mathrm{pH}$ means that an increase in $C_{\mathrm{PEG}}$ with a simultaneous decrease in $\mathrm{pH}$ increase PF. On the other hand, the positive interaction effect between $C_{\mathrm{PEG}}$ and $C_{\mathrm{C}}$ means that simultaneous increase of $C_{\mathrm{PEG}}$ and $C_{\mathrm{C}}$ results in higher $P F$ and enzyme load gives more active enzyme in the top phase.

The selectivity of the systems had higher values ( $S=293$; Table 2) in systems employing $M_{\mathrm{PEG}} 8000$ $\left(\mathrm{g} \mathrm{mol}^{-1}\right), C_{\mathrm{PEG}} 24 \%(\mathrm{w} / \mathrm{w}), C_{\mathrm{C}} 20 \%(\mathrm{w} / \mathrm{w})$ and $\mathrm{pH}$ 6.0. The results of the statistical analysis with the effects of each variable studied in the experimental design to evaluate the selectivity of the systems are shown in Table 3. The only significant negative interaction between $C_{\mathrm{PEG}}$ and $\mathrm{pH}$ on the selectivity was also detected, which means that an increase in $C_{\mathrm{PEG}}$ and a simultaneous decrease in $\mathrm{pH}$ led to higher selectivity. PEG/Citrate ATPS system that has higher selectivity of extraction, obtained moderate $Y$ and $P F$ values (A8; Table 2) while that the systems with high $Y$ and $P F$ values obtained selectivity moderate (A1;
Fig. 3 Pareto chart for the standardized effects of the variables: (1) PEG molar mass- $M_{\mathrm{PEG}}$, (2) PEG concentration- $C_{\mathrm{PEG}}$, (3) citrate concentration $-C_{\mathrm{C}}$ and (4) $\mathrm{pH}$ on purification factor

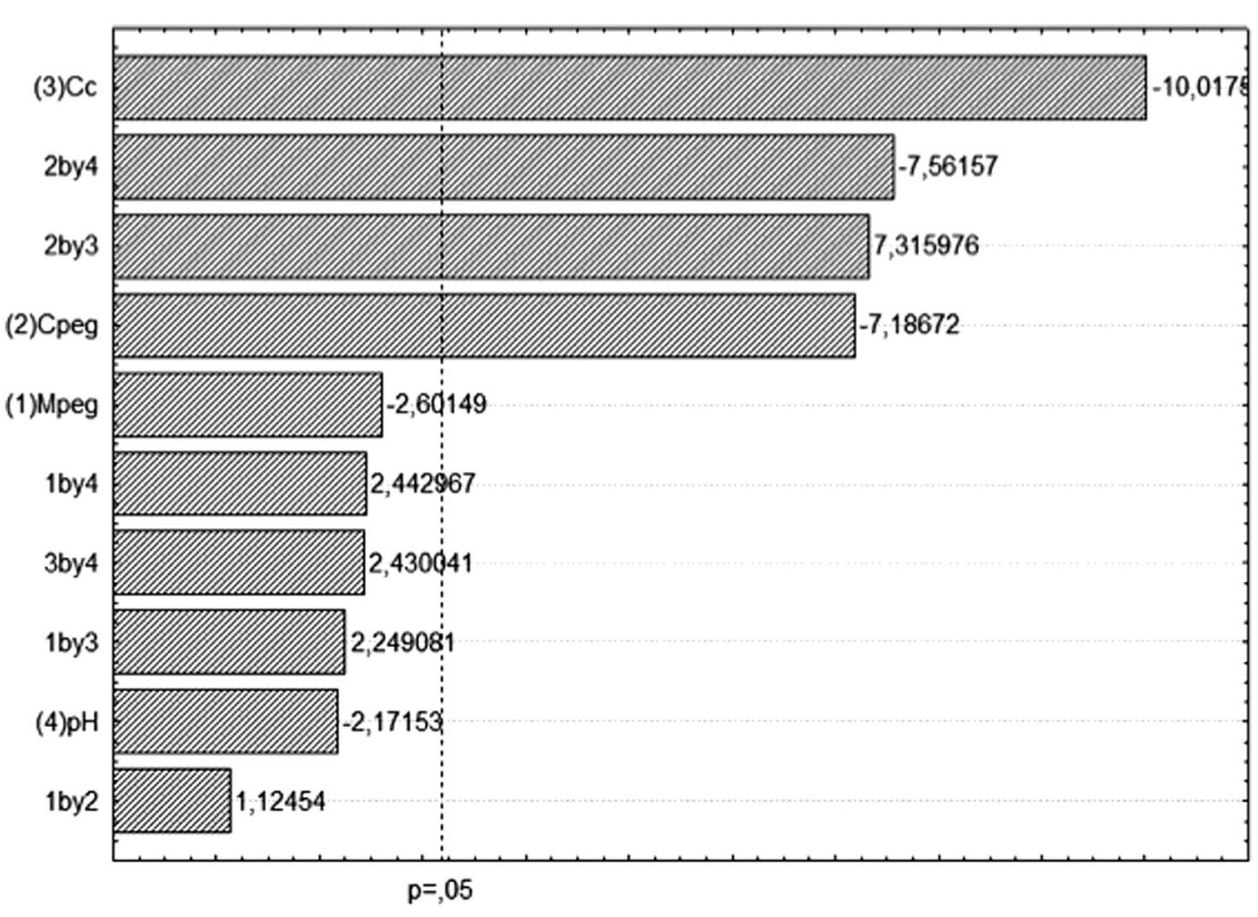

Effect Estimate (Absolute Value) 
Table 2). Therefore, ATPS could be used to selectively purify xylanase from the crude culture in a single-step operation.

\section{Discussion}

Xylanase production by A. japonicus URM5620 in solidstate fermentation (SSF) of castor press cake (Ricinus communis) is influenced by variables substrate amount initial moisture, $\mathrm{pH}$ and temperature. High $\mathrm{XY}$ activities $\left(29,085 \pm 1808 \mathrm{U} \mathrm{g} \mathrm{ds}^{-1}\right)$ were obtained using castor bean meal by solid-state fermentation, denoting that this agroindustrial residue without any addition of nutrient solution is a good substrate for $\mathrm{XY}$ production by $A$. japonicus.

An increase in $\mathrm{pH}$ increases $\mathrm{XY}$ activity (Fig. 1). The enzyme production by microbial strains depends on the initial $\mathrm{pH}$ of the medium as it influences many enzymatic processes and transport of various components across the cell membrane (Prakasham et al. 2005). The present results show that xylanase production was higher with increasing $\mathrm{pH}$ values, obtained high value at $\mathrm{pH}$ 6.0. This is according to $\mathrm{XY}$ production $\left(2012 \pm 18 \mathrm{U} \mathrm{g} \mathrm{ds}^{-1}\right)$ produced by Aspergillus tubingensis FDHN1 in sorghum straw SSF (Adhyaru et al. 2015) and by of Aspergillus tubingensis JP1 using untreated wheat straw (Pandya and Gupta 2012).

Extracellular xylanase production appeared to be sensitive to the initial moisture content of the castor press cake. An increase in the Im reduced xylanase production by A. japonicus URM5620 in Solid-State Fermentation (SSF) of castor press cake (Ricinus communis) (Fig. 1), obtained the highest value at $15 \%$. It showed that water presents several crucial roles in cell metabolism during SSF. The lower xylanase production at higher moisture levels could attribute to alteration in particle structure, decrease in porosity or lower oxygen transfer, whereas the lower moisture content leads to a reduction in the diffusion of the nutrients and oxygen in the substrate, lower degree of swelling and higher water tension (Hasseltine 1972). On the other hand, Soliman et al. (2012) related that $75 \%$ was the optimum initial moisture for xylanase production by $A$. niger (21.32 $\mathrm{U} \mathrm{g} \mathrm{g}^{-1}$ ) in using barley bran and Ang et al. (2015) related that initial moisture of $75-80 \%$ is optimal to xylanase production using Aspergillus fumigatus SK1 cultivated SSF with in oil palm trunk.

The optimum moisture was closely depended on some other parameters such as; organism, desired product as well as nature of substrate (i.e., physical, chemical and their water-binding characteristics, in addition with particle size). Low moisture may reduce the solubility and swelling capacity of substrate causing high-water tension, decreasing growth and enzyme production (Poorna and Prema
2007). Another advantage is that low moisture level in the system by it be easier to control contamination. In contrast, high moisture adversely affects the microstructure between solid particles by creating a gummy texture. This cause the microscopic pores in the solid substrate and thus further interrupts the gas phase between particles, resulting in an anaerobic microenvironment (Chen 2013). Since fungi are known to thrive in moist environments, optimum moisture thus critically controls the success of their growth, as well as the production of metabolites. The moisture content in SSF is a crucial factor that determines the success of the process (Ramesh and Lonsane 1990).

Temperature is one the most significant factors that affects the production of enzyme. Xylanase production peaked at temperature of $25{ }^{\circ} \mathrm{C}$, decreasing above this value. It was also observed by A. niger grown on Jatropha seed cake (Ncube et al. 2012) and Aspergillus oryzae P6B2 cultivated under SSF with using wheat bran (Pirota et al. 2013) The biosynthesis of xylanase by A. oryzae was highly sensitive to variations in temperature, indicating that this variable should be carefully monitored and controlled during the cultivation process. Temperature is important because affect microbial growth, metabolism, and spore germination. In addition, it provides energy for the enzymes to reach the transition state and, thus, induce the enzyme-substrate catalysis reaction (Lu et al. 2008). However, excess energy causes thermo denaturation of the enzymes, which is responsible for the metabolism, causing the fungus to synthesize only essential protein that is crucial for growth (Ogino et al. 2001). It has been shown in a previous study that $A$. tubingensis JP- 1 was unable to produce a considerable xylanase yield above $30{ }^{\circ} \mathrm{C}$ (Pandya and Gupta 2012). On the other hand, Ang et al. (2015) related that maximum xylanase production by Aspergillus fumigatus SK1 cultivated SSF with in oil palm trunk was between 40 and $45^{\circ} \mathrm{C}$ and Adhyaru et al. (2015) found the highest XY production of $1998 \pm 12 \mathrm{U} \mathrm{g} \mathrm{ds}^{-1}$ by Aspergillus tubingensis FDHN1 in sorghum straw SSF at $40{ }^{\circ} \mathrm{C}$. It shows that the type of fermentable wastes and species of microorganisms may also affect the value of incubation temperature.

Xylanase production is also affected by the amount substrate. The effect negative of amount substrate on xylanase production indicates that increasing the substrate amount there are detrimental role on enzyme production in the present study (Fig. 1) shows that high concentration of castor press cake inhibits the enzyme synthesis. Castor press cake concentration mediated regulation of xylanase production in this fungal strain. Of all these tested concentrations of substrate $5 \mathrm{~g}$ showed improved enzyme production. Our findings were in accordance with Suvarna Lakshmi et al. (2009) who also reported that when increase the substrate level, it caused reduction of xylanase production by using A. terreus grown on rice straw in SSF. 
In current research, $A$. japonicus URM5620 was a higher xylanase producer $(29,085 \pm 1808 \mathrm{U} / \mathrm{g}$ ds; Table 1) compared to A. fumigatus SK1 under SSF using untreated oil palm trunk (418.7 $\mathrm{U} \mathrm{g}^{-1}$ ) and by Aspergillus awamori IOC-391 using babassu cake $\left(835.0 \mathrm{U} \mathrm{g}^{-1}\right.$; Castro et al. 2015).

PEG/citrate ATPS was effectively used to extract the extracellular xylanase produced by A. japonicus URM5620 from the crude enzymes. In this work, $K$ values indicate the effectiveness of partitioning to the top phase (Mazzola et al. 2008). In the general, most of the purified xylanase activity by ATPS was collected in the top phase (Garai and Kumar 2013; Yang et al. 2008). Usually the partition coefficient decreases as the PEG chain length increases, behavior also observed in the present case for the proteins and xylanase enzymes. As the bio-molecule size increases, its preference for partitioning into one phase also tends to increase. Another aspect that should be taken into account is the relative hydrophobicity of the enzyme surface. For bio-molecules with similar size and net charge, a higher presence of hydrophobic regions at the molecule surface tends to enhance its preference for the polymer phase, an aspect that eventually can also explain the differences in the partitioning behavior of the xylanase enzymes observed in the present work. Xynalase from Aspergillus candidus exhibits a high preference for the top phase as expected for a hydrophobic enzyme as observed by Garai and Kumar (2013) using ATPS composed of PEG 4000/ $\mathrm{NaH}_{2} \mathrm{PO}_{4}$ system.

The recovery of active enzyme and PF in the top phase decreased with increase in $C_{\mathrm{C}}$ (Table 2). This would result in salting out of proteins and increased partition to the top phase, providing a lower $\mathrm{Y}$ in this phase. Furthermore, PEG is known to refold the enzyme increase their activity. As mentioned, other reports have suggested that PEG promotes proper refolding, playing a similar function to that of chaperone proteins (Sánchez-Trasviña et al. 2015; Cleland and Wang 1990). This same effect was observed in xylanase from Bacillus halodurans in the PEG-phosphate two-phase systems (Rahimpour Mamo et al. 2007) and invertase from $S$. cerevisiae in PEG-potassium phosphate (Sánchez-Trasviña et al. 2015).

The highest value of $Y(268 \%)$ and $P F(7.16)$ was obtained in the top phase systems composed by $M_{\mathrm{PEG}}$ $1000\left(\mathrm{~g} \mathrm{~mol}^{-1}\right), C_{\mathrm{PEG}} 20 \%(\mathrm{w} / \mathrm{w}), C_{\mathrm{C}} 15 \%(\mathrm{w} / \mathrm{w})$ and $\mathrm{pH} 6.0$, indication that xylanase was purification of contaminant proteins with high enzymatic yield. This promising result was due to xylanase partition to the two phases almost to the same extent, while the other proteins preferably partitioned to the bottom phase, providing to be an excellent system for purification of the xylanase in a single-step operation. Yang et al. (2008) extracted and purified xylanase one step in ATPS composed by PEG and
$\left(\mathrm{NH}_{4}\right)_{2} \mathrm{SO}_{4}$, obtaining the purity of the target xylanase is comparable to obtained from column chromatography. Thus, the ATPS is demonstrated to be efficient and inexpensive xylanase purification if the correct conditions are selected.

Values of the yield higher than $100 \%$ have been reported for enzyme extraction using liquid-liquid (Porto et al. 2008; Cavalcanti et al. 2006). Sánchez-Trasviña et al. (2015) related that o PEG can refold the enzyme increase their activity. Pancera et al. (2000) reported that PEG can influence enzyme activity, because alteration of the structure of enzyme active site in the presence of PEG might enhance its relative activity. Mayerhoff et al. (2004) this behavior with the elimination of inhibitors from the PEG phase during the extraction as well as with the very composition of the system, which may favor the enzymatic activity.

This investigation has clearly established the effect of growth conditions on the production of xylanase by Aspergillus japonicus URM5620 showing it to be a potential microorganism for the XY using SSF. Temperature, $\mathrm{pH}$, moisture and substrate amount were significant factors to enzymatic production. No addition of expensive media is required and the use of inexpensive agro-industrial wastes will have important economic advantages. In addition, we investigated the effects of environmental conditions on xylanase purification in PEG/citrate aqueous two phase systems ATPS, including the system composition, the PEG molecular weight, PEG concentration, Citrate concentration and $\mathrm{pH}$ values. Partial purification was attained, with a good compromise between the purification factor and the yield was achieved within the experimental domain investigated using a simple and inexpensive procedure. A purification factor of 7.16 and a yield as high as $268 \%$ in top phase was obtained for Xylanase in the system containing $M_{\mathrm{PEG}} 1000\left(\mathrm{~g} \mathrm{~mol}^{-1}\right)$, $C_{\text {PEG }} 20 \%(\mathrm{w} / \mathrm{w}), C_{\mathrm{C}} 15 \%(\mathrm{w} / \mathrm{w})$ and $\mathrm{pH}$ 6.0. These results demonstrate the feasibility of single-step a xylanase purification in PEG-citrate ATPS with low environmental toxicity.

Castor press cake can be used in SSF to xylanase production by Aspergillus japonicus URM5620 as well as this enzyme can be extracted by PEG/Citrate ATPS system.

Acknowledgments The authors acknowledge to the support provided by FINEP Ref. 2083/07- CNPq Process No. 552410/2005-5, RENORBIO/MCT/CNPq Process No. 554740/2006-0 and CAPES for providing financial support to this research work. The author gratefully the Culture Collection Micoteca URM, of the Mycology Department from UFPE, Brazil.

\section{Compliance with ethical standards}

Conflict of interest The authors declare no conflict of interest associated with this research. 
Open Access This article is distributed under the terms of the Creative Commons Attribution 4.0 International License (http:// creativecommons.org/licenses/by/4.0/), which permits unrestricted use, distribution, and reproduction in any medium, provided you give appropriate credit to the original author(s) and the source, provide a link to the Creative Commons license, and indicate if changes were made.

\section{References}

Adhyaru DN, Bhatt N, Modi HA (2015) Optimization of upstream and downstream process parameters for cellulase-poor-thermo solvent stable xylanase production and extraction by Aspergillus tubingensis FDHN1. Bioresour Bioprocess 3:2-14

Ang SK, Shaza EM, Adibah Y, Suraini AA, Madihah MS (2013) Production of cellulases and xylanase by Aspergillus fumigatus SK1 using untreated oil palm trunk through solid state fermentation. Process Biochem 48:1293-1302

Ang SK, Adibah Y, Abd-Aziz S, Madihah MS (2015) Potential uses of xylanase-rich lignocellulolytic enzymes cocktail for oil palm trunk (OPT) degradation and lignocellulosic ethanol production. Energy Fuel 29:5103-5116

Bradford MM (1976) A rapid and sensitive method for the quantification of protein utilizing the principle of protein-dye binding. Anal Biochem 72:248-254

Bailey MJ, Biely P, Poutanen K (1992) Interlaboratory testing of methods for assay of xylanase activity. J Biotechnol 23:257-270

Castro AM, Castilho LR, Freire MG (2015) Multivariate optimization and supplementation strategies for the simultaneous production of amylases, cellulases, xylanases, and proteases by Aspergillus awamori under solid-state fermentation conditions. Appl Biochem Biotechnol 175:1588-1602

Cavalcanti MTH, Porto TS, Neto BB, Lima-Filho JL, Porto ALF, Pessoa A Jr (2006) Aqueous two-phase systems extraction of $\alpha$ toxin from Clostridium perfringens type A. J Chromatogr B 833:135-140

Chen H (2013) Modern solid state fermentation: theory and practice. Springer, Dordrecht, pp 1-332

Cleland JL, Wang DI (1990) Cosolvent assisted protein refolding. Biotechnol (N Y) 8:274-1278

Collins T, Gerday C, Feller G (2005) Xylanases, xylanase families and extremophilic xylanases. FEMS Microbiol Rev 29:3-23

Gao J, Weng H, Zhu D, Yuan M, Guan F, Xi Y (2008) Production and characterization of cellulolytic enzymes from the thermoacidophilic fungal Aspergillus terreus M11 under solid-state cultivation of corn stover. Bioresour Technol 99:623-7629

Garai D, Kumar V (2013) Aqueous two phase extraction of alkaline fungal xylanase in PEG/phosphate system: optimization by BoxBehnken design approach. Biocatal Agric Biotechnol 2:125-131

Glyk A, Scheper T, Beutel S (2015) PEG-salt aqueous two-phase systems: an attractive and versatile liquid-liquid extraction technology for the downstream processing of proteins and enzymes. Appl Microbiol Biotechnol 99:6599-6616

Hasseltine CW (1972) Solid state fermentations. Biotechnol Bioeng 14:517-532

Herculano PN, Lima DMM, Fernandes MJS, Neves RP, Souza-Motta CM, Porto ALF (2011) Isolation of cellulolytic fungi from waste of castor (Ricinus communis L.). Curr Microbiol 62:1416-1422

Herculano PN, Porto TS, Maciel MHC, Moreira KA, Souza-Motta CM, Porto ALF (2012) Partitioning and purification of the cellulolytic complex produced by Aspergillus japonicus URM5620 using PEG-citrate in an aqueous two-phase system. Fluid Phase Equilib 335:8-13
Ho HL, Lau LY (2014) Bioprocessing of agricultural wastes as optimized carbon source and optimisation of growth conditions for xylanase production by Aspergillus brasiliensis in agitated solid state fermentation (Ssf). J Biodivers Biopros Dev $1: 121-125$

Instituto Adolfo Lutz (2005) Métodos físico-químicos para análise de alimentos, 4 edn. Brasília: Ministry of Health

Irfan M, Nadeem M, Quratulain S (2014) One-factor-at-a-time (OFAT) optimization of xylanase production from Trichoderma viride-IR05 in solid-state fermentation. J Radiat Res Appl Sci 7:317-326

Khammuang S, Sarnthima R (2007) Laccase from spent mushroom compost of Lentinus polychrous Lev. and its potential for remazol brilliant blue $\mathrm{R}$ decolourisation. Biotechnology 6:408-413

Lu FX, Lu M, Lu ZX, Bie XM, Zhao HZ, Wang Y (2008) Purification and characterization of xylanase from Aspergillus ficcum AF-98. Biresour Technol 99:5938-5941

Mayerhoff ZDVL, Roberto IC, Franco TT (2004) Purification of xylose reductase from Candida mogii in aqueous two-phase systems. Biochem Eng J 18:217-223

Mazzola PG, Lopes AM, Hasmann FA, Jozala AF, Penna TCV, Magalhães PO, Rangel-Yagui CO, Pessoa JRA (2008) Liquidliquid extraction of biomolecules: an overview and update of the main techniques. J Chem Technol Biotechnol 83:143-157

Miller GL (1959) Use of dinitrosalicylic acid reagent for determination of reducing sugars. Anal Chem 31:426-428

Mutlu H, Meier MAR (2010) Castor oil as a renewable resource for the chemical industry. Eur J Lipid Sci Technol 112:10-30

Ncube T, Howard RL, Abotsi EK, Rensburg JEL, Ncube I (2012) Jatropha curcas seed cake as substrate for production of xylanase and cellulase by Aspergillus niger FGSCA733 in solid-state fermentation. Ind Crops Prod 37:118-123

Ogino H, Uchiho T, Yokoo J, Kobayashi R, Ichise R, Ishikawa $\mathrm{H}$ (2001) Role of intermolecular disulfide bonds of the organic solvent-stable PST-01 protease in its organic solvent stability. Appl Environ Microbiol 67:942-947

Oliveira CHA, Silva LM, Silva AM, Fernandes CCL, Góes KLS, Duarte SS, Rodrigues FV, Bertolini LR, Bezerra FJ, Gomes Filho MA, Rondina D (2013) Anatomic and tissue characteristics in goats fed for extended periods with residue of castor biodiesel production. Semina: ciências Agrárias. Londrina 34:2865-2878

Pancera SM, Silva LHM, Loh W, Itri R, Pessoa A Jr, Petri DFS (2000) The effect of poly(ethylene glycol) on the activity and structure of glucose-6-phosphate dehydrogenase in solution. Colloid Surf B 26:291-300

Pandya JJ, Gupta A (2012) Production of xylanase under solid state fermentation by Aspergillus tubingensis JP-1 and its application. Bioprocess Biosyst Eng 35:769-779

Pirota RDPB, Tonelotto M, Delabona PS, Fonseca RF, Paixao DAA, Baleeiro FCF, Neto VB, Farinas CS (2013) Enhancing xylanases production by a new Amazon Forest strain of Aspergillus oryzae using solid-state fermentation under controlled operation conditions. Ind Crops Prod 45:465-471

Poorna A, Prema P (2007) Production of cellulase-free endoxylanase from novel alkalophilic thermotolerent Bacillus pumilus by solid-state fermentation and its application in wastepaper recycling. Bioresour Technol 98:485-490

Porto TS, Medeiros-e-Silva GM, Porto CS, Cavalcanti MTH, Neto BB, Lima-Filho JL, Converti A, Porto ALF, Pessoa A Jr (2008) Liquid-liquid extraction of proteases from fermented broth by PEG/citrate aqueous two-phase system. Chem Eng Prog 47:716-721

Prakasham RS, SubbaRao C, Rao RS, Rajesham S, Sarma PN (2005) Optimization of alkaline protease production by Bacillus sp.

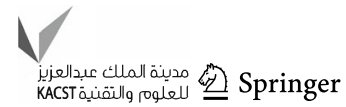


using Taguchi methodology. Appl Biochem Biotechnol 120: 133-144

Rahimpour Mamo G, Feyzi F, Maghsoudi S, Hatti-Kaul R (2007) Optimizing refolding and recovery of active recombinant Bacillus halodurans xylanase in polymer-salt aqueous two-phase system using surface response analysis. J Chromatogr A 1141:32-40

Raja S, Murty VR, Thivaharan V, Rajasekar V, Ramesh V (2011) Aqueous two phase systems for the recovery of biomolecules: a review. Sci Technol 1:7-16

Ramesh MV, Lonsane BK (1990) Critical importance of moisture content of the medium in alpha-amylase production by Bacillus licheniformis M27 in a solid state fermentation system. Appl Microbiol Biotechnol 33:501-505

Rito-Palomares M, Lyddiatt A (2002) Process integration using aqueous two-phase partition for the recovery of intracellular proteins. Chem Eng J 28:313-319

Rodrigues RA (2007) Programa nacional de produção e uso de biodiesel: uma referência para a análise da formulação, implementação e avaliação de políticas públicas. Revista de Políticas Públicas e Gestão Governamental, Brasília 6:9-25

Sánchez-Trasviña CS, Gonzáles-Valdes J, Mayolo-Deloisa K, RitoPalomares M (2015) Impact of aqueous two-phase system design parameters upon the in situ refolding and recovery of invertase. J Chem Technol Biotechnol 90:1765-1772
Soccol CR, Faraco V, Karp S, Vandenberghe LPS, Thomaz-Soccol V, Woiciechowski A, Pandey A (2011) Chapter 5: Lignocellulosic bioethanol: current status and future perspectives. In: Pandey A, Larroche C, Ricke SC, Dussap CG, Gnansounou E (eds) Biofuels alternative feedstocks and conversion processes. Elsevier, pp 101-122

Soliman HM, Sherief AA, EL-Tanash AB (2012) Production of xylanase by Aspergillus niger and Trichoderma viride using some agriculture residues. Int J Agric Res 7:46-57

Spier MR, Greiner R, Rodriguez-León JA, Woiciechowski AL, Pandey A, Soccol VT, Soccol CR (2008) Phytase production using citric pulp and other residues of the agroindustry in SSF by fungal isolates. Food Technol Biotechnol 46:178-182

Suvarna Lakshmi G, Subba Rao C, Srinivas Rao R, Hobbs PJ, Prakasham RS (2009) Enhanced production of xylanase by a newly isolated Aspergillus terreus under solid state fermentation using palm industrial waste: a statistical optimization. Biochem Eng J 48:51-57

Yang S, Huang Z, Jiang Z, Li L (2008) Partition and purification of a thermostable xylanase produced by Paecilomyces thermophila in solid state fermentation using aqueous two-phase systems. Process Biochem 43:56-61 